\title{
神戸空港海底地盤における洪積粘土層の 原位置圧密挙動
}

\author{
長谷川憲孝 ${ }^{1} \cdot$ 松井保 $^{2} \cdot$ 田中泰雄 ${ }^{3} \cdot$ 高橋嘉樹 $^{4} \cdot$ 南部光広 $^{5}$ \\ ${ }^{1}$ 正会員 神戸市みなと総局（二650-8570 神戸市中央区加納町 6-5-1） \\ E-mail : noritaka_hasegawa@office.city. kobe.jp \\ 2フェロー会員 福井工業大学建設工学科（910-8505 福井市学園 3-6-1） \\ E-mail : matsui@ccmails. fukui-ut.ac.jp \\ 3 正会員 神戸大学都市安全研究センター（†657-0013 神戸市灘区六甲台町 1-1） \\ E-mail : ytgeotec@kobe-u. ac. jp \\ ${ }^{4}$ 正会員 株式会社不動テトラ 神戸支店（† 651-0084 神戸市中央区磯辺通 2-2-3） \\ E-mail : yoshiki.takahashi@fudotetra.co.jp \\ ${ }^{5}$ 正会員 応用地質株式会社 関西支社（†532-0021 大阪市淀川区田川北 2-4-66） \\ E-mail : nanbu-mitsuhiro@oyonet.oyo.co.jp
}

\begin{abstract}
神戸空港は神戸港沖に埋立造成して築造されたが，海底地盤には洪積層が厚く堆積している．大阪湾の 洪積粘土は擬似過圧密粘土とされており，その挙動については不明確な部分が多い。あわせて海成粘土層 の間に堆積している砂砶，砂，粘土の互層部の排水能力が不明確であった。これらのことを解明するため に, 洪積層において区閒変位測定器および多深度間隙水圧計により圧縮量や間隙水圧の測定を行った. 対 象としたのは, 埋立荷重により正規圧密状態に入ると思われる洪積層の上部に分布する Ds1〜Ds3 層（互層 部）と Ma12 層，Ma11 層の上部である. 計測の結果, Ma12 層の上部については実測による圧密降伏応力を 把握することができ, 室内土質試験より求められた值に対する低下率を把握することができた.あわせて, 互層部の排水能力の高いことが確認できた。
\end{abstract}

Key Words : Kobe Airport, Pleistocene clay, soil property, consolidation, pore pressure, settlement

\section{1. まえがき}

神戸空港は平成 18 年 2 月に開港した海上空港であり, 平成 11 年 9 月から護岸工事を行ってきた. 建設地の地 盤は, 海成粘土層 (Ma 層) とその間に分布する砂碟, 砂, 粘土の互層よりなっている. 大阪湾に堆積する海成粘土

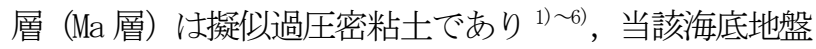
では上位より Ma13 層, Asc 層 (以上沖積層), Ma12 層〜 Ma9 層（上部洪積層～大阪層群）が深さ $300 \mathrm{~m}$ 位までに厚 く堆積している. 埋立造成に当たっては，沖積層だけで なく，洪積層の圧縮特性も詳細に把握する必要があり， それらを把握するために Ma12 層, Ma11 層の上部ならび にMa12 層とMa13 層との間の砂碟, 砂, 粘土の互層部 (Ds1 ～Ds3 層）に各種計器を埋設して，各層毎の圧縮量と間 隙水圧を測定した. 用いた計測器は $1 \mathrm{~m}$ 毎の圧縮量が計 れる区間変位測定器, 各深度の間隙水圧を 1 孔で測定す ることのできる多深度間隙水圧計である. 本論文におい ては，当該海底地盤の特徴，用いた計測器の内容ならび に計測結果を述べるとともに，神戸沖洪積層の圧密特性
について述べる.

\section{2.＼cjkstart海底地盤の地層構成および土質特性}

(1) 地層構成

図-1 は神戸空港の平面形状であり,長尺ボーリング位 置 B-1, B-2 の位置もあわせて示している. 図-2 は図-1 に示す東西方向の断面（I-I’ 断面）である. また, 図-3 には旧海底面および沖積層下端面コンター図を, 図-4に は Ma12 層下端面のコンター図を示す. これらの図は数 10 本に及ぶボーリングと音波探査の結果から求めたも のである ${ }^{7)}$. 同図に示すように地層は北西方向から南東 方向に向かって緩く傾斜しており, 各層の層厚も南東方 向ほど厚くなっている．傾斜の程度は年代の古い下部層 程高くなっている. 分布する地層は沖積層である Ma13 層とAsc 層，それらの下部には洪積層である砂砶，砂， 粘土の互層（Ds 層）と海成粘土層（Ma 層）が交互に分 布している. 互層部では Ds1-Ds3 層が最も厚く, その厚 さは 30〜40m に達している. 一方, 洪積粘土層は, Ma9 層 


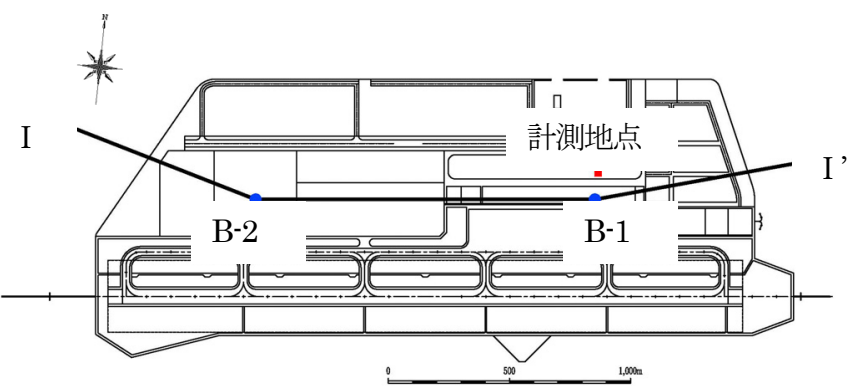

図-1 神戸空港の平面形状

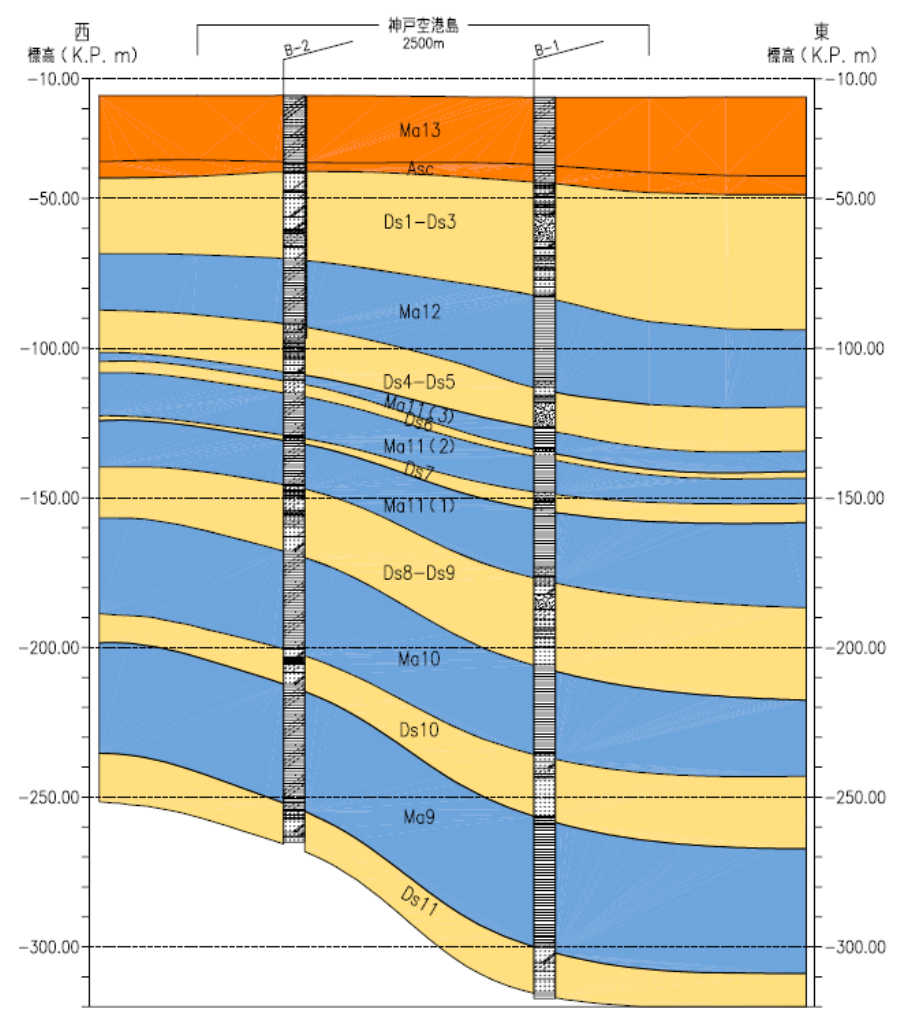

図-2 地質想定断面（ I-I’ 断面）

が 35〜40m と層厚としては最も厚い. Ma11 層は下部より Ma11 (1) 層, Ma11 (2) 層, Ma11 (3) 層と 3 層に分かれており, 下部の Ma11 (1) 層が 15 30m と 3 層の中では最も厚い. 砂碟，砂，粘土の互層ならびに洪積粘土層とも南東方向 になるほど層厚が厚くなっている，洪積粘土層のう ち, Ma12 層と Ma11 層は上部洪積層に, Ma10 層と Ma9 層 は大阪層群に分類される. ここで調査深度をMa9 層まで としたのは, 近接するポートアイランド (II 期) における 実測結果より,Ma9 層より下部層についてはほとんどで 圧縮していないことによる. 寸なわち，参考文献 77,81 に 示しているように，水深はわずかに深くなっているだけ であるのに対して，Ma9 層の下面は約 50m 深くなってお り，ポートアイランド（II 期）と地盤条件，載荷条件が 良く似ていることによる. なお，Ma9 層より下部層の圧 縮については本論文で述べていないが，ロッド式沈下計 で確認しており，実測データでも圧縮していない．

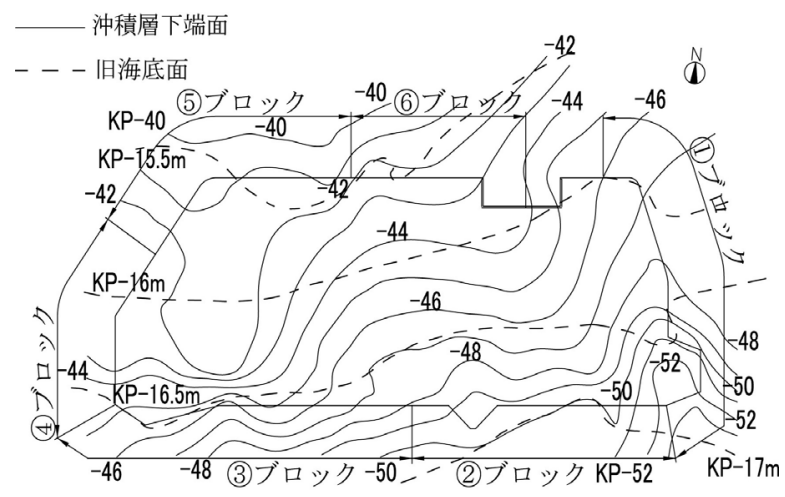

図-3＼cjkstart旧海底面および沖積層下端面コンター

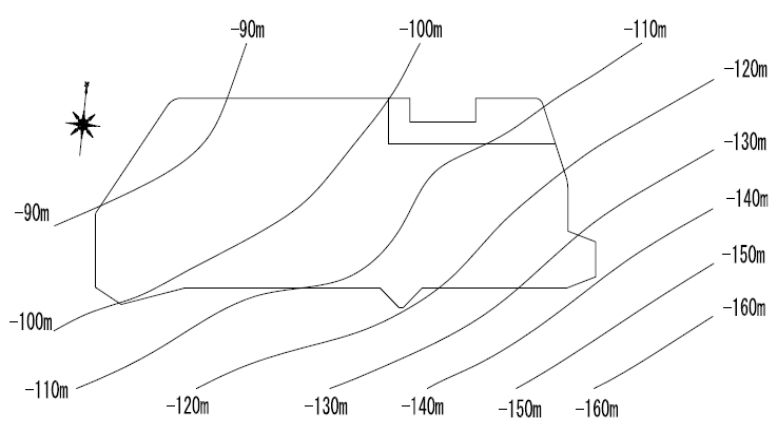

図-4 Ma12 層下端コンター

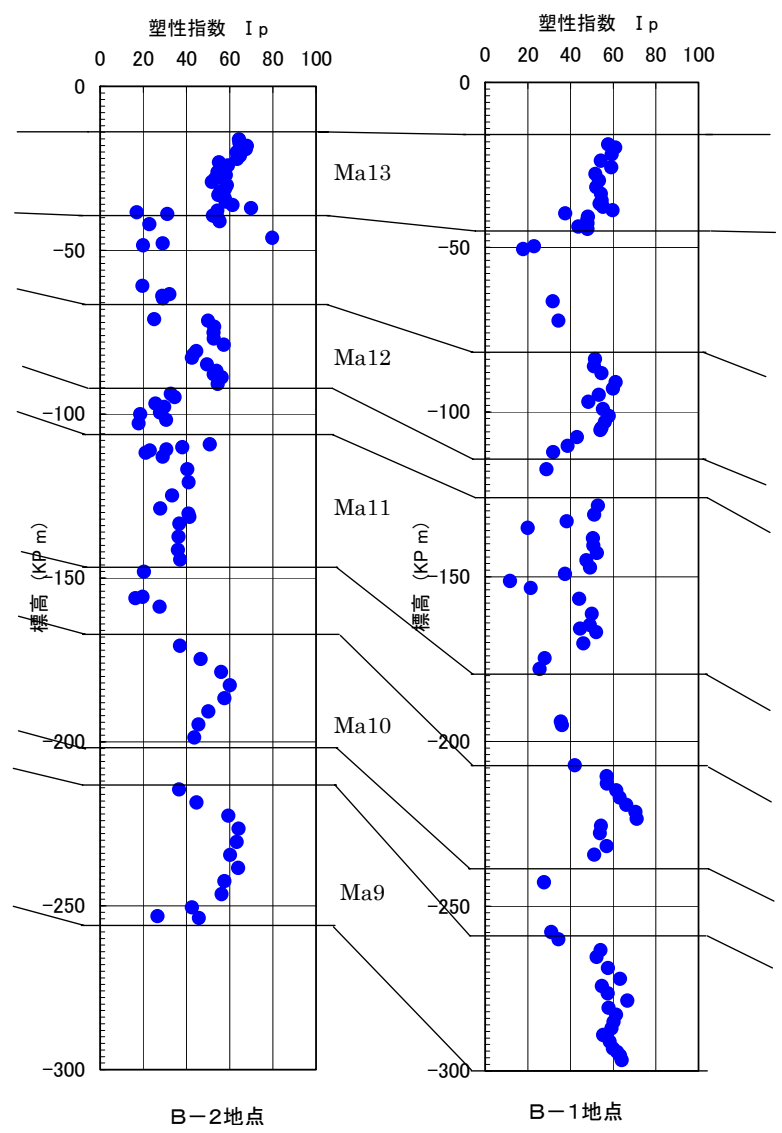

図-5 各層の塑性指数

\section{（2）土質特性}

図-1 に示す B-1，B-2 の長尺ボーリングにて採取され た試料に対して各種土質試験を実施した。

図-5 は B-1，B-2 地点における塑性指数（Ip）の深度 

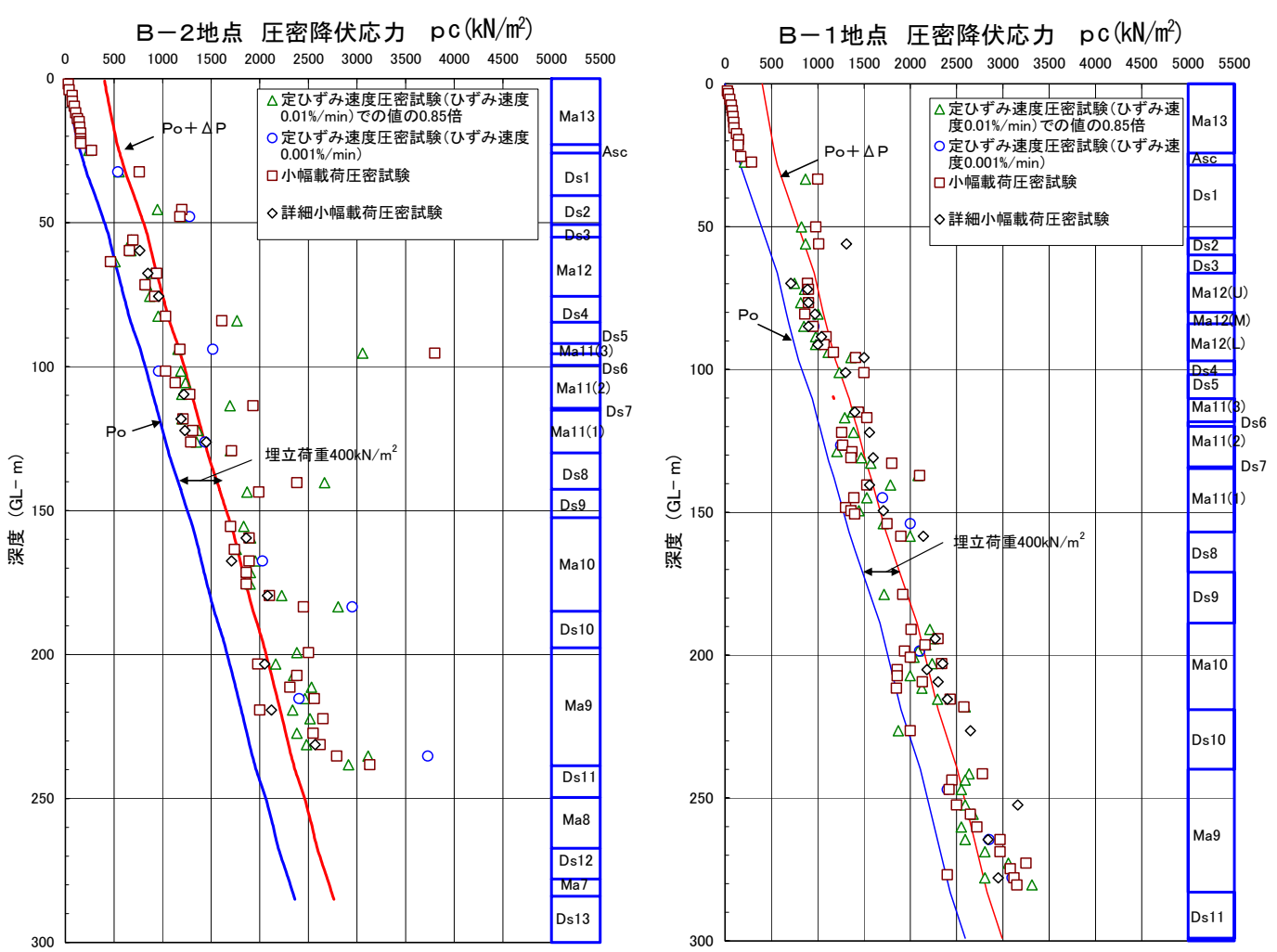

図-6 B-1 地点, B-2 地点での $P_{C}$ 深度分布

変化を示したものである．同図から洪積粘土層の塑性指 数は, Ma11 層が他の Ma 層に比べると低い塑性指数を示 している. B-1，B-2 の比較では，東側に位置している B-1 の方が全般にわずかではあるが，それぞれの層毎に 高い塑性指数を示している.

図-6 は B-1，B-2 地点における圧密降状応力の深度方 向の分布を示したものである. 圧密試験としては定ひず み速度圧密試験 (ひずみ速度 $(\dot{\varepsilon}) 0.01 \% / \min$ と $0.001 \%$ $/ \mathrm{min})$, 小幅載荷圧密試験，載荷幅をより細かくした詳 細小幅載荷圧密試験を実施している。ここで定ひずみ速 度圧密試験（ひずみ速度 $0.01 \% / \mathrm{min}$ ）から得られた $P_{C}$ 值については実地盤での $P_{C}$ 值よりも大きい值を示して いる可能性が高く, 同図では試験值を 0.85 倍した值で プロットしてある.ここで 0.85 倍した理由は，小幅載 荷圧密試験，さらに荷重の刻み幅を小さくした詳細小幅 載荷試験などから得られた $P_{C}$ 值と上記試験結果 $P_{C}$ 值と を比較した結果, 概祆試験值 $P_{C}$ を $0.85 \sim 0.90$ 倍した值 に近づいたことによるものである. 図-6によっても試験 值を 0.85 倍することによって, 他の試験值と同じ範囲 に分布していることからも妥当であることがわかる．同 図によると洪積層は過圧密状態にあり, 圧密降伏応力

$\left(P_{C}\right)$ 值より現在の有効土被り荷重 $(P o)$ 值を差し引い た過圧密量は深度が深くなるほど大きくなっている，た だ，その割合は西側に位置寸る B-2 地点の方が大きい. B-1 と B-2 を比べると B-2 の方が広範囲に值が分布して いる. この原因としては西側に位置する B-2 地点での粘
土層は B-1 地点での粘土層に比べてシルト分が多く, 年 代効果による擬似過圧密状態が不均一になっている度 合いが高いためと推察される.特に深度 $100 \mathrm{~m}$ 付近や $150 \mathrm{~m}$ 付近， $180 \mathrm{~m}$ 付近， $240 \mathrm{~m}$ 付近で大きな $P_{C}$ を示しているの は, Ma 層と Dg 層との層境もしくはDs 層内の粘土層での データであり，堆積時の乾燥や砂分含有の影響を受けて いるためと推察される. 両地点を通して特徽的なのは, B-1，B-2 地点とも各洪積粘土層の $P_{C}$ 值は深度方向には 大きくなっているが, ある地層から $P_{C}$ 值が極端に大きく なっているところが認められないことである. 同図には, 埋立前の有効土被り荷重（Po） とそれに埋立荷重 $\left(400 \mathrm{kN} / \mathrm{m}^{2}\right)$ を加えた荷重線を示しているが, 上部の Ma11, Ma12 層は埋立荷重を加えるとほぼ正規圧密状態となり, それより下部の Ma10，Ma9 層でもそれに近づくことがわ かる.

\section{3. 現地計測計画}

\section{(1) 対象層}

今回計測の対象としたのは, Ds1～Ds3 層, Ma12 層, Ma11 (3) 層である. これらの層は埋土荷重により正規圧 密の領域に入るものと考えられた地層である. その際に 圧密沈下に大きく影響を与える $P_{C}$ 值が図-6 で示した值 と比べてどの程度であるかということを把握するため に, 図-1に示寸地点において詳細な計測を行うこととし た. 

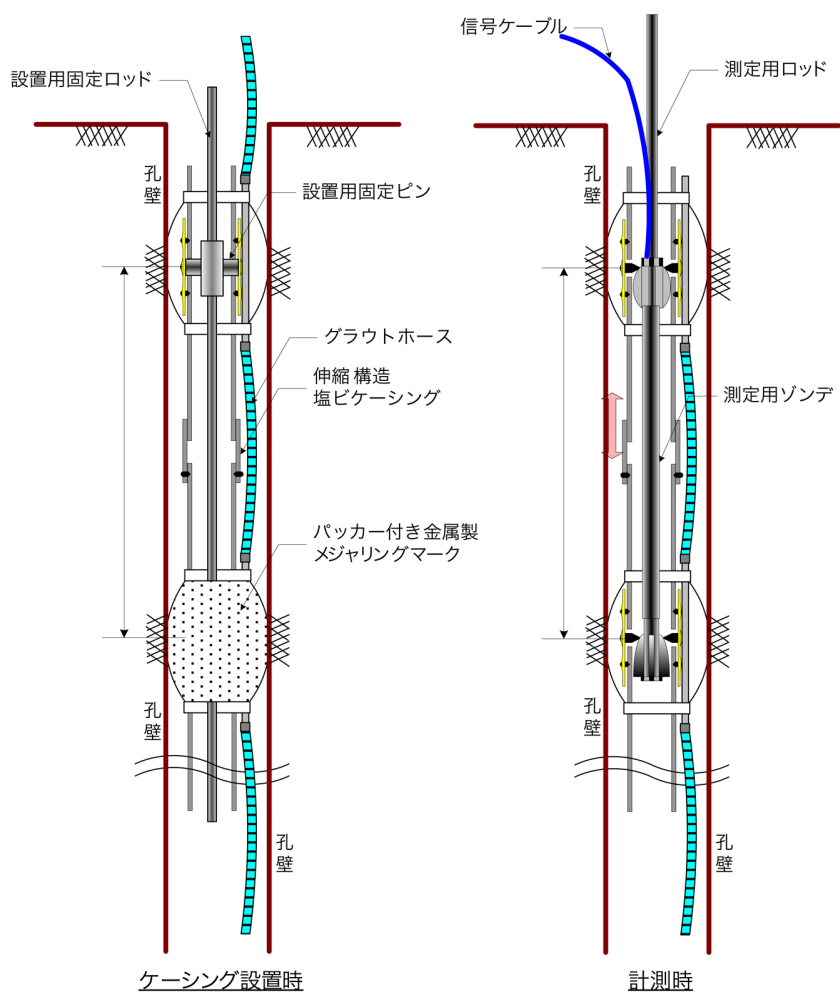

図-7 区間变位測定器設置・測定方法

\section{(2) 埋設計器}

\section{a）計器の選定}

圧密の進行に伴って生じる圧縮量については, 各地層 中で可能な限り細かな区間に区切り，それぞれの区間圧 縮量として捉えることが必要である.このことにより， 地盤中の区間変位を $1 \mathrm{~m}$ 間で連続的に測定できる機器と して，区間変位測定器を採用することとした．次に， 間隙水圧についても多深度で同時測定できる測定器と して多深度間隙水圧計を採用することとした.

\section{b） 区間変位測定器}

区間変位測定器は地盤に設置した測定孔（メジャリン グマークおよびケーシング）と手動挿入式の測定器とか らなる. ゾンデおよびメジャリングマークは 4 方向に突 起があり，それぞれ $90^{\circ}$ 回転させると通過姿勢から測定 姿勢の状態となる．このメジャリングマーク間の距離変 化を測定することによって, 各深度での圧縮量を経時的 に計測できることになる.

各メジャリングマークおよびケーシングは, 図-7 に示 す布パッカーを膨らますことによって地盤中に固定す る.ケーシング (パッカー付き金属製メジャリングマー ク十伸縮構造塩ビケーシング）は，伸縮部の動きにでき るだけ抵抗無く追随させるため，設置後は各メジャリン グマーク同士の連結が無い状態としている.そのため, 設置時には各メジャリングマークを固定するロッドを 使用し，設置後にロッドを抜去する. 計測の対象として は図-6 に示寸Ds1～Ds3 層, Ma12 層, Ds4〜Ds5 層の上端 部である. 図-8 に区間变位測定器の計測深度を示した。

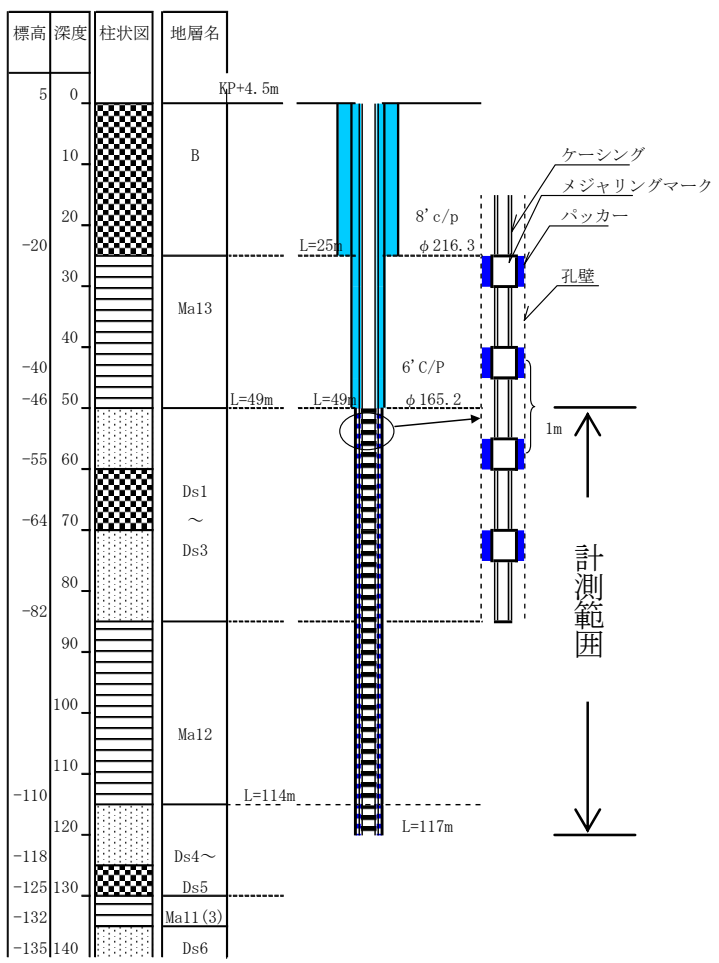

図-8 区間変位測定器設置深度
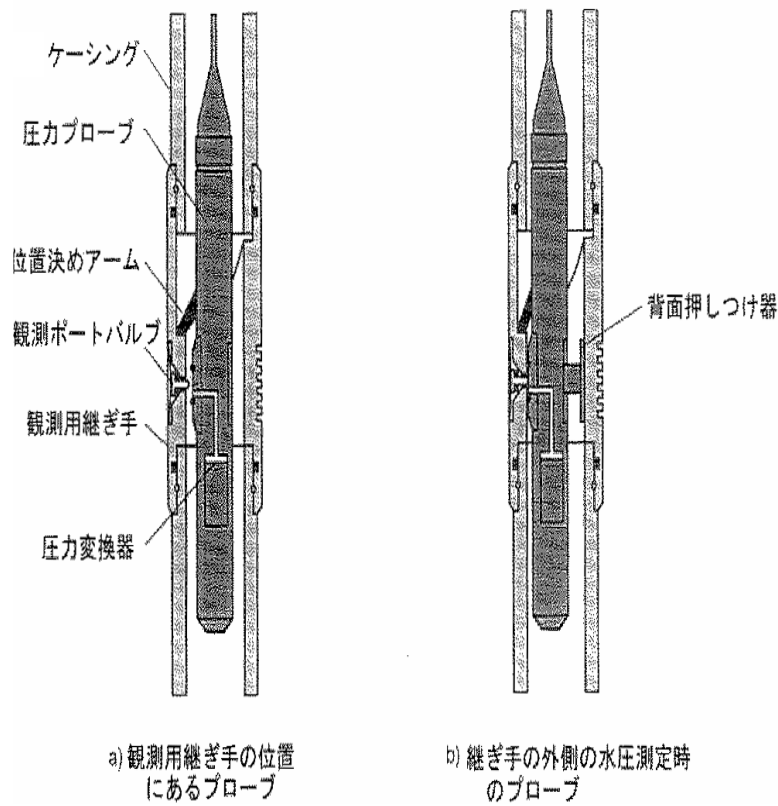

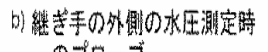
0 งึด

図-9 間隙水圧測定時のプローブ状況

測定は, ケーシング内ヘゾンデを挿入し, 図-7 に示す $1 \mathrm{~m}$ 毎に設置したメジャリングマーク間の距離変化を連続 的に測定する．測定用ゾンデの精度としては，1/100m である。

測定器は縮み側と伸び側の両方が測定できるが，今回 は埋立に伴うメジャリングマーク間の縮み量を測定す ることより，地盤の圧縮量を測定した。

\section{c）多深度間隙水圧計}

多深度間隙水圧計は，地中に設置したケーシング部品， 


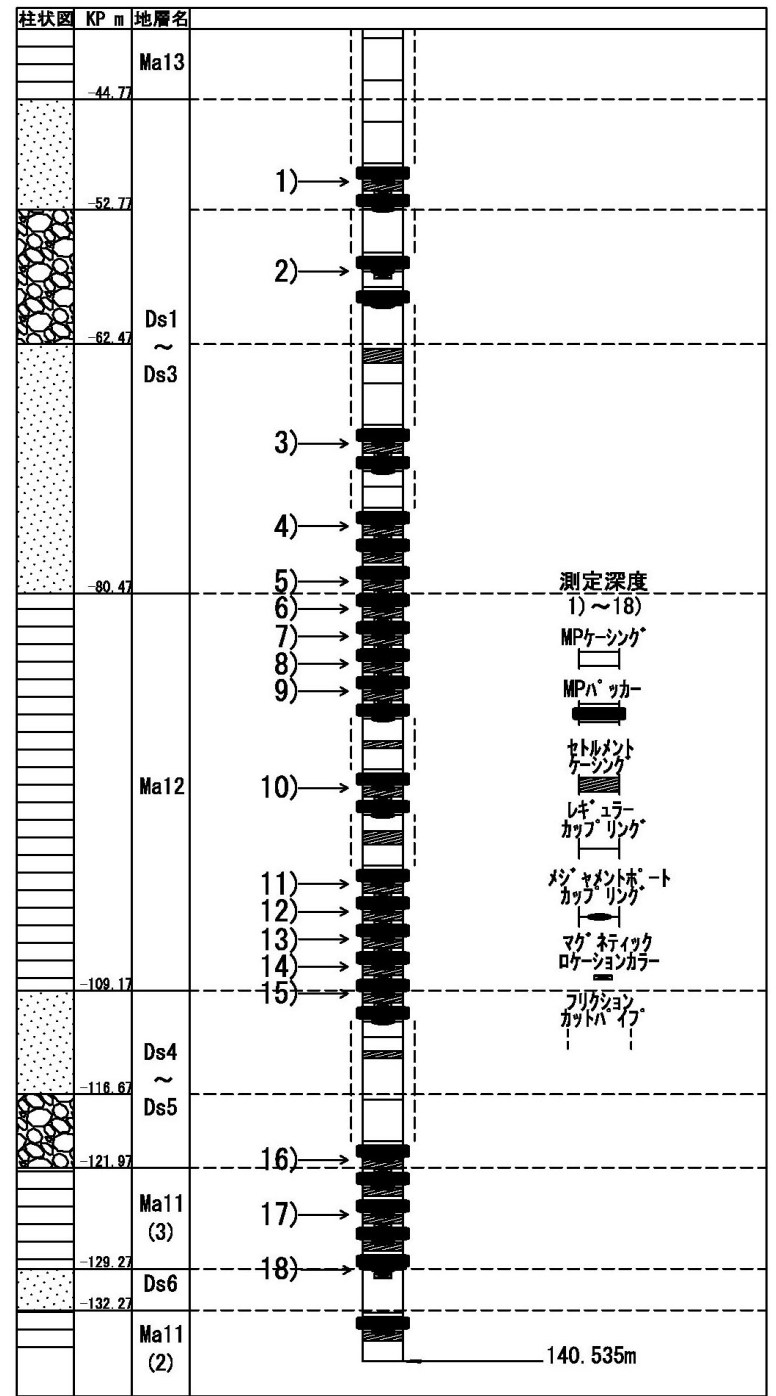

図-10 多深度間隙水圧計による間隙水圧測定位置

挿入式の圧力測定プローブおよび専用の道具より構成 される. ケーシング部品はいろいろな長さのケーシング とそれ繋ぐ継ぎ手，継ぎ手に取り付けられてある観測ポ ートバルブを上下で外圧と遮断するパッカーからなる.

間隙水圧の測定については，各継ぎ手にプローブをセ ットし，観測用のポートバルブの水圧を測定する．間隙 水圧測定時のプローブの状況を図-9 に示寸. 設置後に生 じる管の圧縮に対しては，座屈を防止するためテレスコ ーピング (多深度間隙水圧計用ケーシングが 2 重管構造 になったもの）を粘性土部分に配置し，圧縮を吸収する。 図-10 には多深度間隙水圧計による間隙水圧測定深度を 示した. 同図の 1)～18)に示寸ように Ma12 層の上, 下端 部には数多くの観測ポートを設けた.

\section{4. 計測結果}

\section{（1） 区間変位測定器測定結果}

区間変位測定器による $1 \mathrm{~m}$ 毎の圧縮量測定結果を図-11 に示寸，同図では設置最下端であるDs4 層よりの累積変
位量（累積土縮量）として表している．なお，同期間の 埋立履歴（盛土高さ変化）については後述する図-14の 左上に示している. 図-12 は $1 \mathrm{~m}$ 毎の区間変位量 (区間圧 縮量）を示したものであり，Ma12 層については，上部の 排水境界で圧縮量が急増することがわかる．あわせて時 間の経過とともにそれらが Ma12 層の内部にまで及んで いく様子がわかる.これに対して Ma12 層の下部では, あまり圧縮の進んでいないことがわかる．特に下端部に おいては, 後述する多深度間隙水圧計による測定結果よ り間隙水圧が消散しているにも関わらず，圧縮があまり 生じていないことになる. これは図-6 の B-1 で見られる ように Ma12 層の下端部においては大きな圧密降伏応力 を示しており，埋立荷重を加えても正規圧密領域に入っ ていないことによるものと思われる. 図-12 によると砂 磒, 砂, 粘土の互層部である Ds1〜Ds3 層の圧縮量は Ma12 層に比べて小さいが，局部的に大きくなっているところ が見られる．これらは主としてシルト・粘土層に相当す るところが多く，互層部でも細粒分が多くなっている所 では，圧縮量が大きくなる傾向が認められる.

\section{（2）多深度間隙水圧計測定結果}

多深度間隙水圧計の測定結果を図-13 に示寸．また， 各深度での経時変化図を図-14に示寸.図-13によると, Ds1〜3 層の間隙水圧は低いが，Ma12 層については，層 の中央部で水圧が高い状態である. 図-14 によると盛土 とともに各部の間隙水圧は上昇しているが，Ds1〜3 層, Ds4 層での間隙水圧は上昇していないことがわかる。こ れは砂砅，砂，粘土の互層部が排水能力の高い層である ことを示している. 一方, Ma12 層各部の間隙水圧は引き 続く盛土がなければ上昇せずに一部小さくなっている ところも見受けられる. 平成 16 年 3 月〜 5 月に一部変化 の激しいところが認められるが，これについては，周辺 で杭打ちが行われたことより，それの影響が表れている ためと思われる.さらに平成 16 年 8 月以降, 間隙水圧 がわずかに大きくなっているのは周辺部で盛土造成が なされたことによるものである.Ma11 (3) 層でも間隙水 圧は上昇しているが, その值は Ma12 層ほど顕著でない. さらに Ma11 (3) 層と Ma11 (2) 層間の Ds6 層の間隙水圧は 地層の層厚が薄いにも関わらず，大きくは上昇していな い. ただ，上部の Ds1Ｄs3 層に比べると大きな值を示 している.このことは, Ds6 層も排水能力を有している が，その能力は Ds1Ｄs3 層ほど高くないことを示して いる.

\section{5. 圧密特性の評価}

2 章で述べたように, 洪積粘士層の圧密降伏応力 $\left(P_{C}\right)$ については，ひずみ速度依存性があり，事前に行う室内 


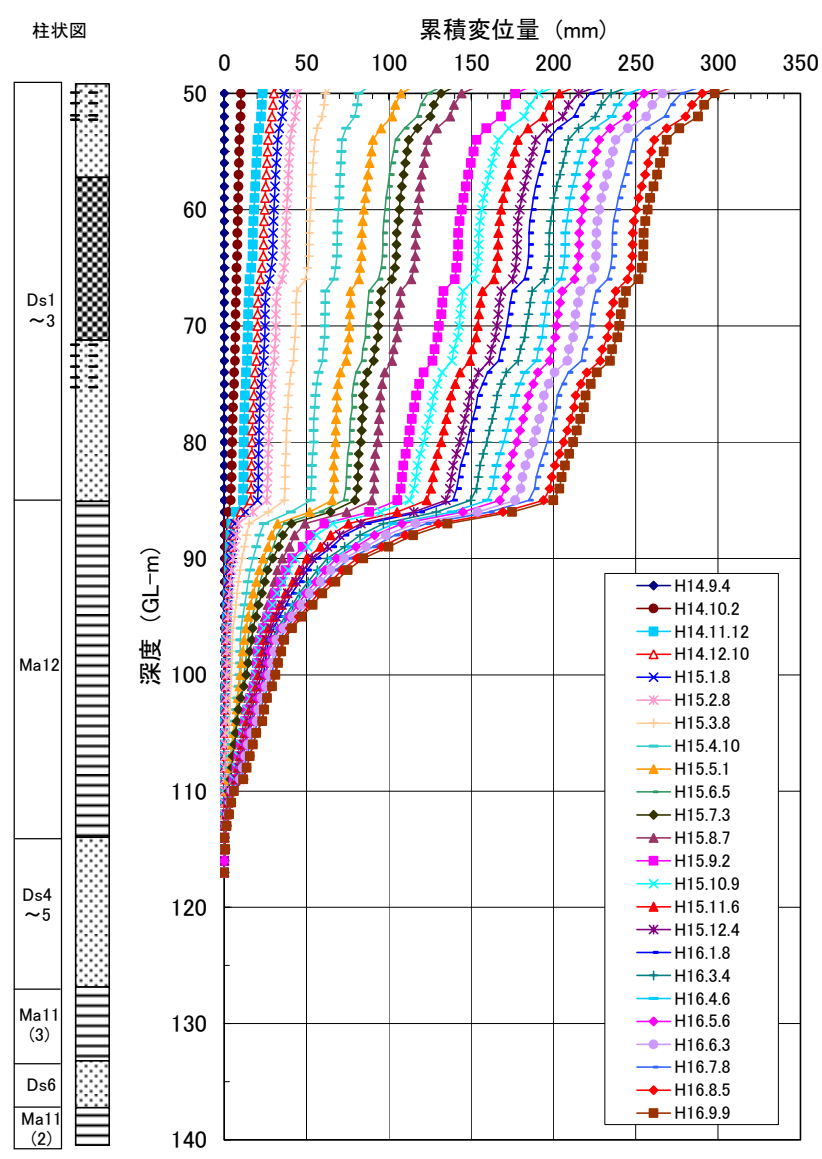

図-11 区間変位測定器測定結果（累積変位量）

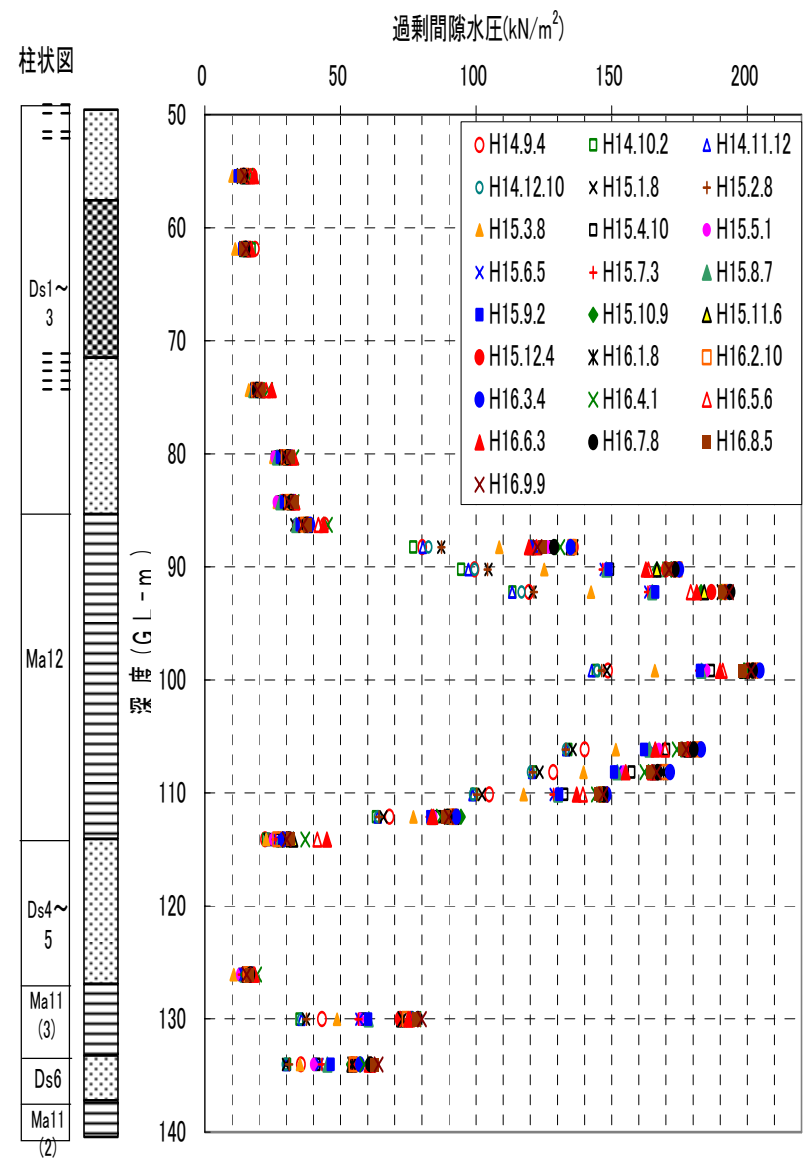

図-13 多深度間隙水圧計による間隙水圧測定結果

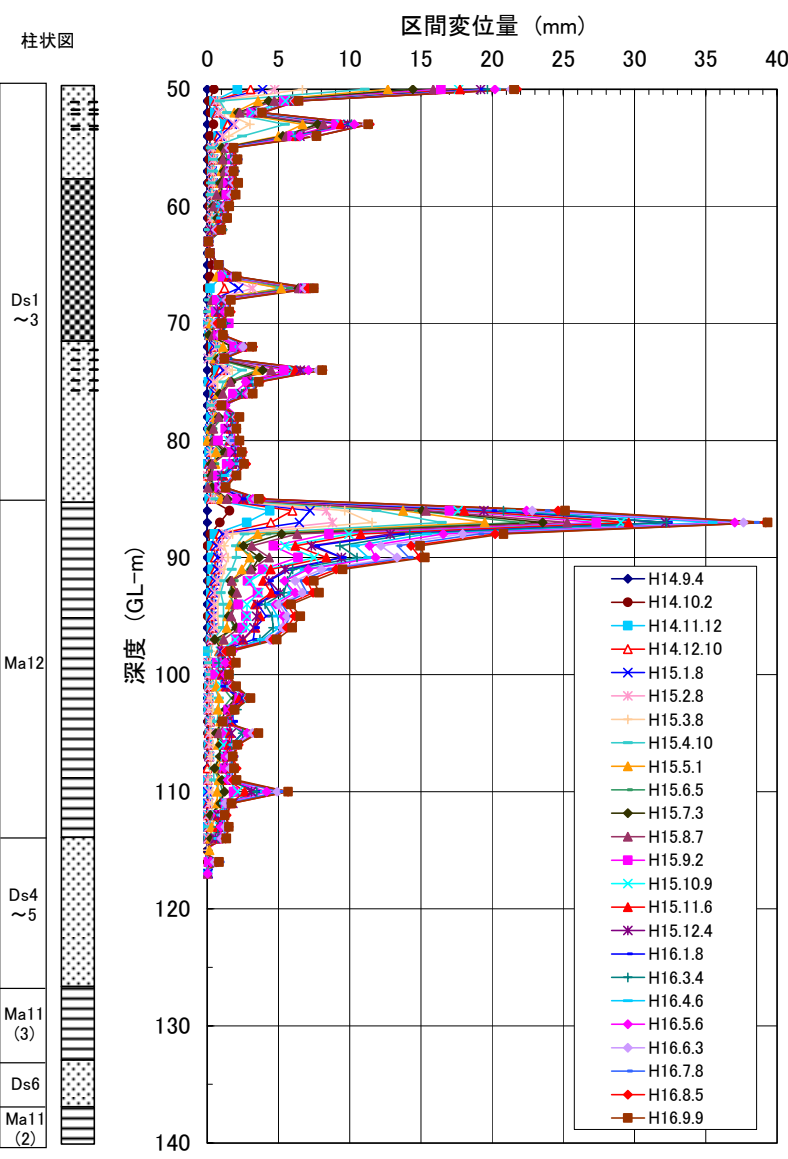

図-12 区間変位測定器測定結果（区間変位量）

試験結果からだけでは，実地盤での挙動が十分に予測で きない面があったこのことより，今回測定された区間 毎の圧縮量と間隙水圧の測定結果より原位置における Ma12 層の圧密降伏応力を評価することとした.

図-15 は Ma12 層の各点における過剩間隙水圧の経時変 化を示したものである. 左上の図は計測地点における盛 土高を示しているが，盛土の進行と共に過剩間隙水圧が 大きくなっていることがわかる，ただ，盛土の進行は地 表面の各箇所で異なっており, 周辺の盛土高が図-15 左 上に示した盛土高と同じでない，このことより盛土に伴 って発生する過剩間隙水圧は, 周辺部での盛土進行の影 響を受けたものとなっている. なお，平成 16 年 3 月〜 5 月に一部変化の激しいところが認められるが，これらに ついては，前述したように新交通駅舎工事などにより， 周辺で杭打ちが行われた影響が表れているものと推察 される.

図-16 は区間変位測定器計測により得られた各深度で の $1 \mathrm{~m}$ 間の圧縮量を時系列で示したものである.これら のデータはMa12 層全層について得られているが，図-16 では代表的なもののみ示している．図-17 は実測の区間 圧縮量と過剩間隙水圧より各深度毎の $\mathrm{e}^{-}-10 g \mathrm{P}$ 関係を示 したものである. ここで, 有効応力 $(P)$ は図-16 に示寸各 盛土時点での全応力をブーシネスクの方法で求め, 多深 

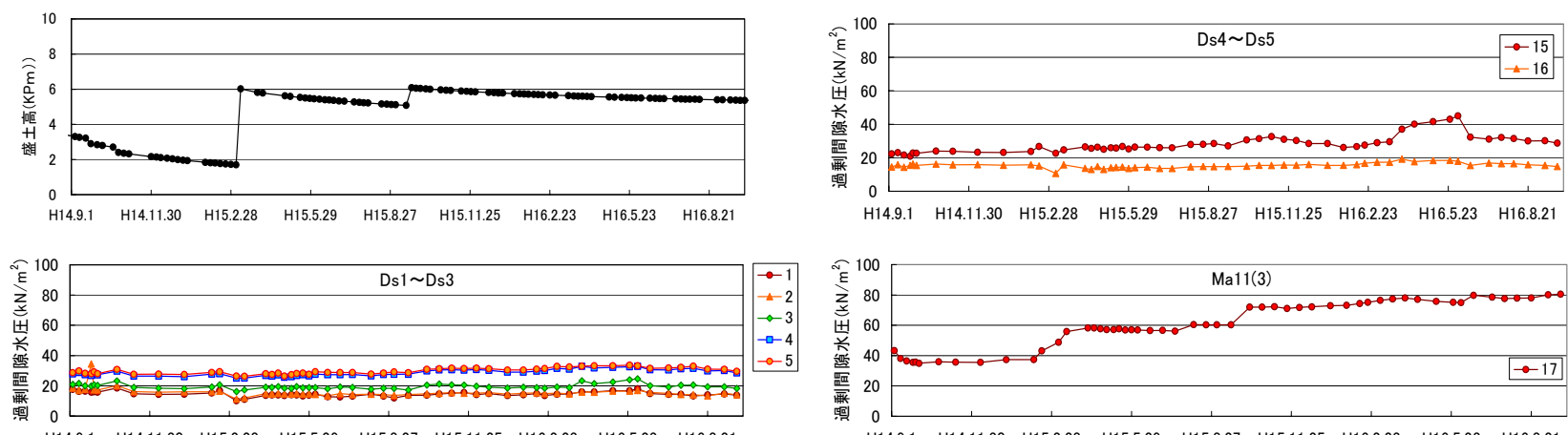

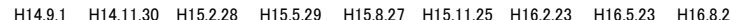
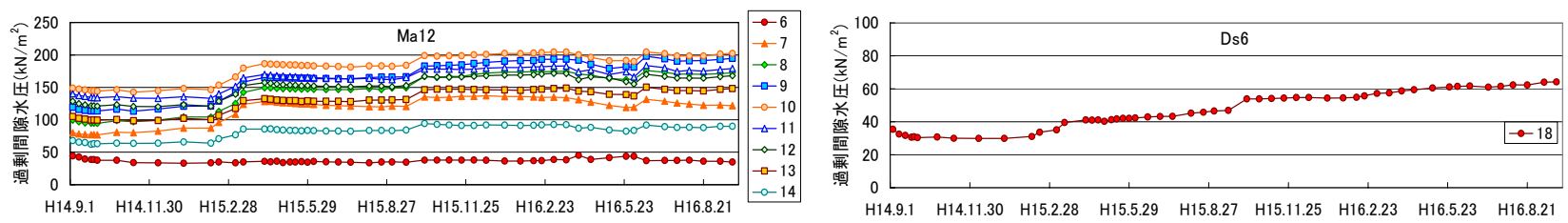

注）測定番号の深度については図ー10に示している.

図-14 過剩間隙水圧経時変化
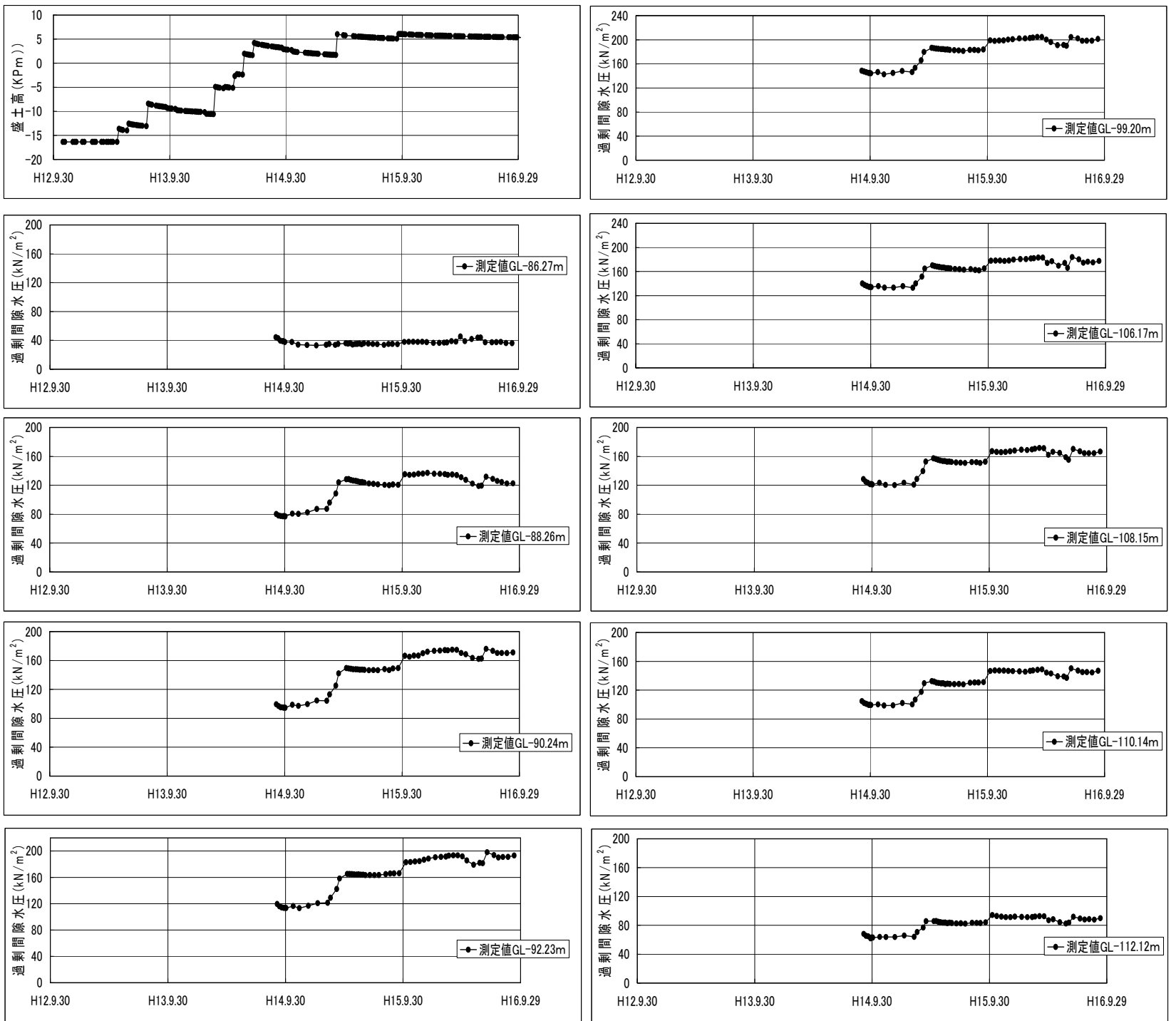

図-15 Ma12 層の過剩間隙水圧の経時変化 

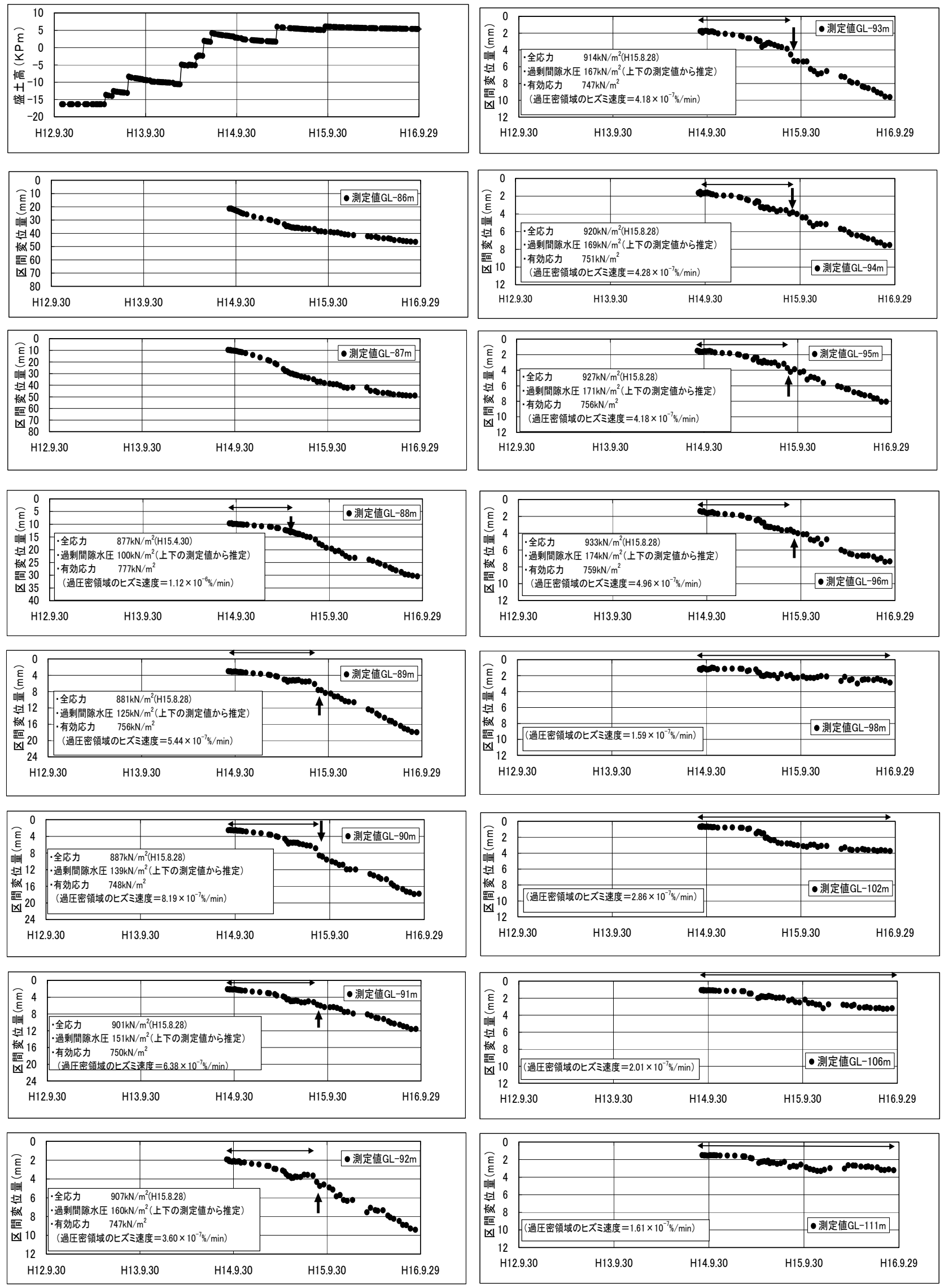

図-16 Ma12 層の区間（1m 間）圧縮量の経時変化 

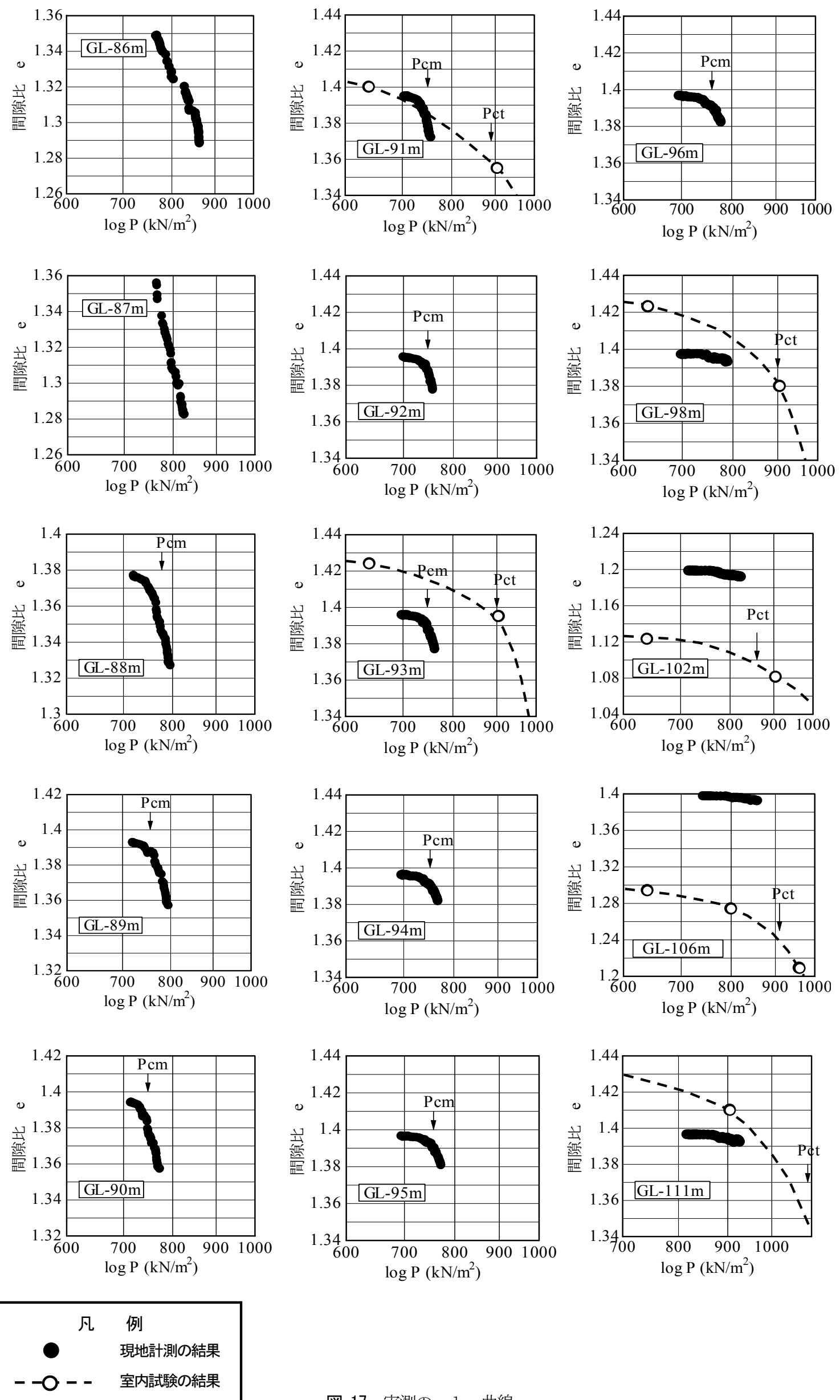

図-17 実測の $\mathrm{e}^{-}-\log$ 曲線 

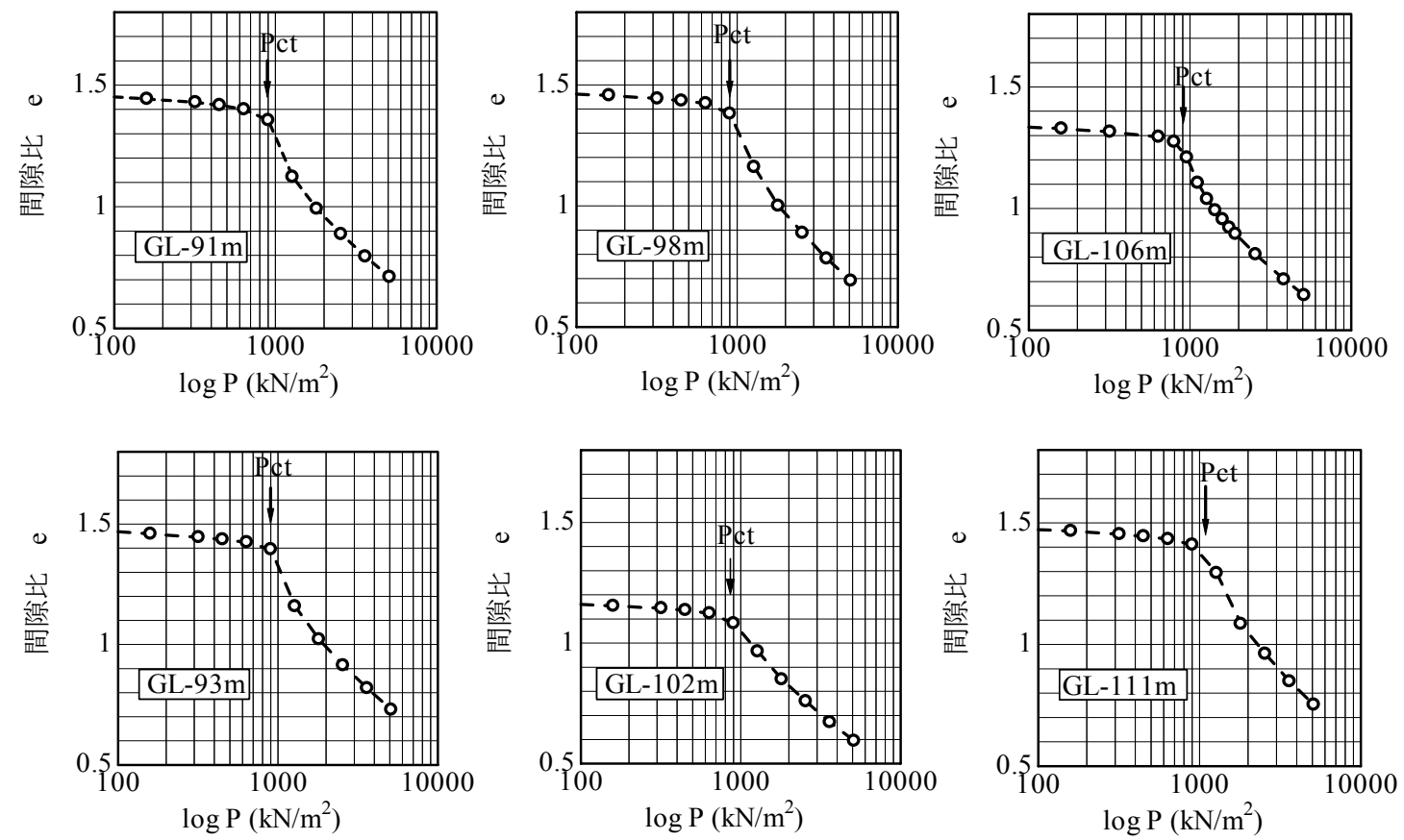

図-18 小幅載荷圧密試験の $\mathrm{e}^{-}-\log \mathrm{P}$ 曲線

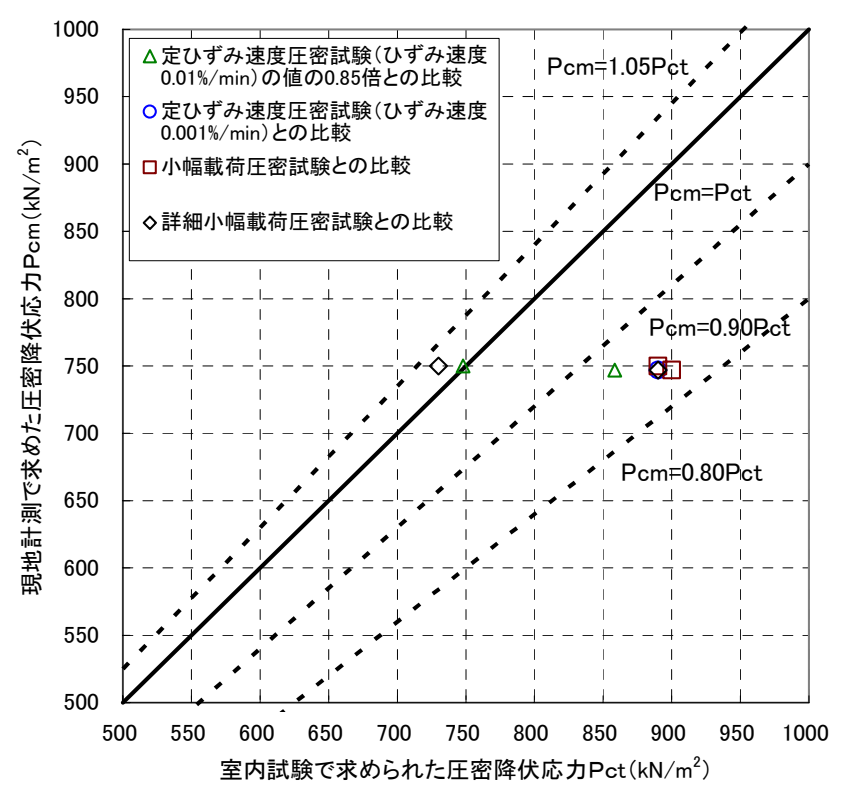

図-19 圧密降伏応力 $\left(P_{C}\right)$ の実測值と室内試験值との比較

度間隙水圧計で得られた過剩間隙水圧を差し引いて求 めたものである. プロットされている各点は図-16の各 点に相当している. 一方, 間隙比については, 埋立前の 採取試料に対して室内試験より求められていた平均的 な間隙比 $\left(\mathrm{e}_{0}\right)$ から，実測された区間圧縮量より得られ る間隙比減少分 $(\triangle \mathrm{e})$ を差し引いて求めたものである.

図-18に示寸室内試験で得られた $\mathrm{e}-\log \mathrm{P}$ 曲線を図-17 に併記する，同図には，深度毎に実測の $\mathrm{e}^{-}-10 \mathrm{~g}$ 曲線より 得られた圧密降伏応力 $\left(P_{C}\right)$ を示している. これらの点 は，図-16において矢印として示しており，Ma12 層上部 において過圧密領域から正規圧密領域に移っていくこ とがとらえられている，同図の各欄には，全态力，過剩 間隙水圧，有効応力の值を示しているが，全応力は矢印

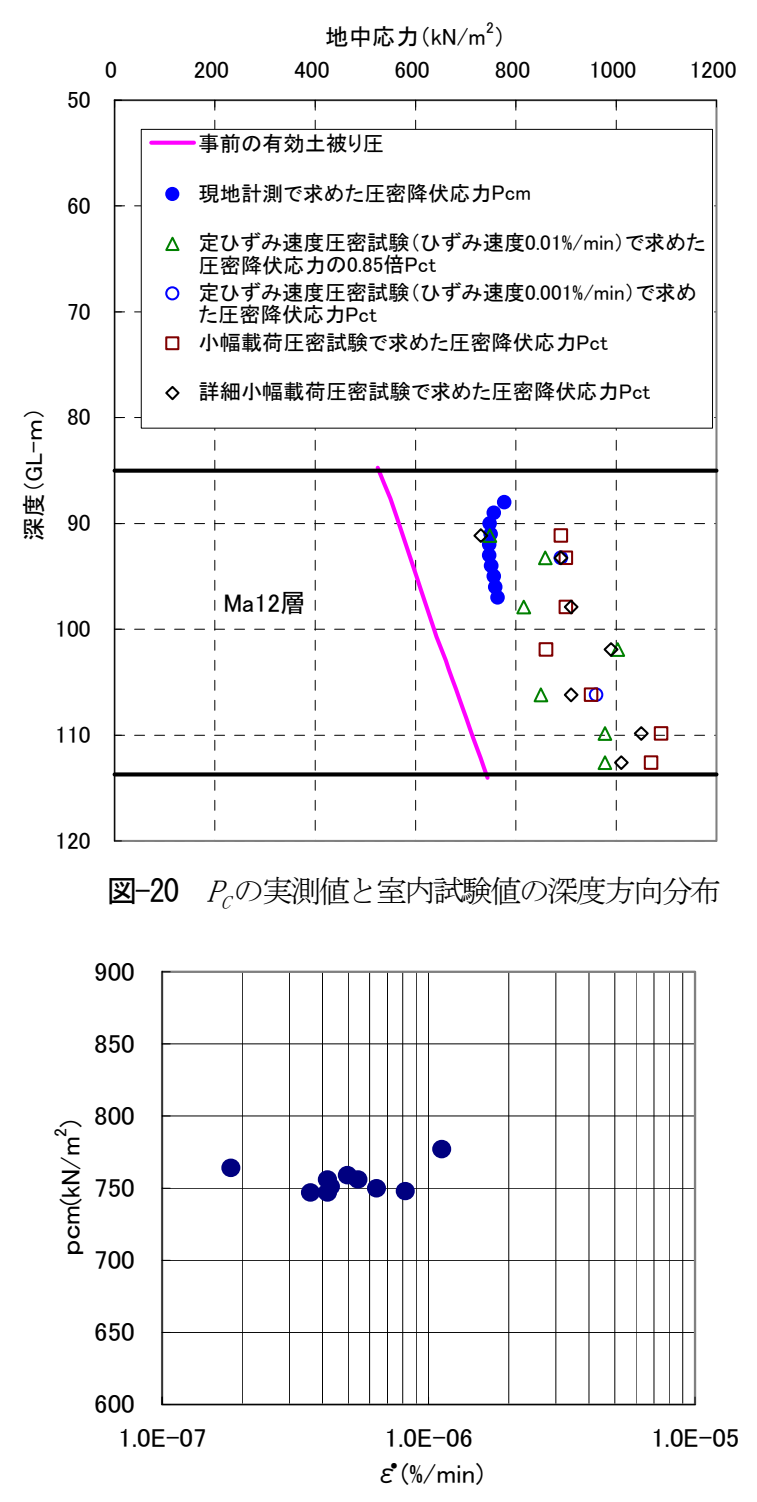

図-21 ひずみ速度 $(\dot{\varepsilon})$ と $P_{C}$ との相関 
で示す時点において，盛土荷重ならびに海底地盤構成土 層の荷重よりブーシネスクの方法 ${ }^{6}$ にて各計測深度での 全応力を求めたものである. 次に過剩間隙水圧は, 図-12 に示寸多深度間隙水圧計の計測結果より，図-16 の矢印 を示守時点での過剩間隙水圧を求めた值である. そして, 有効応力は全応力より過剩間隙水圧を差し引いた值で ある。

図-16, 17 によると圧密の進行に伴って Ma12 層上部で は過圧密領域から正規圧密領域に移っているが，深度 GL-98m 以深では計測時点で正規圧密領域に入っていな いことがわかる. 図-16 には過圧密領域のひずみ速度を 示しているが，全般に深度が深くなるにしたがって，ひ ずみ速度が小さくなっていることがわかる.

図-19 と図-20 は室内試験より得られたP P t と Ma12 層 の実測より得られた $P c m$ の比較図である.ここで室内試 験より得られた $P_{C}$ 值については, 計測地点が $\mathrm{B}-1$ 地点に 近いことより, 埋立前の B-1 地点でのデータとの比較を 行っている. また，図-17 には同一深度での小幅載荷試 験より得られた $\mathrm{e}^{-} \log$ 曲線を併記している。 これらによ ると, 現地計測で求められた圧密降伏応力 $(P \mathrm{~cm})$ は, 室内試験で求められた值 $(P c t)$ と比べて, 同程度かもし くは小さくなっている. 計測点数が少なく, 判然としな い面があるが，概ね Pcm=(0.8〜1.0) Pct となっている.

図-21 は，図-16 に示したグラフより過圧密領域の平 均的なひずみ速度と現地計測から得られた圧密降伏応 力 $(P \mathrm{~cm})$ の相関を取ったものである. 同図によると, ひずみ速度が遅くなるにしたがって,多少 $P_{C}$ が小さくな っているが，その傾向は必ずしも明瞭ではない，次に， 埋立前海底地盤の有効土被り荷重 $(P o)$ に対して, ひ

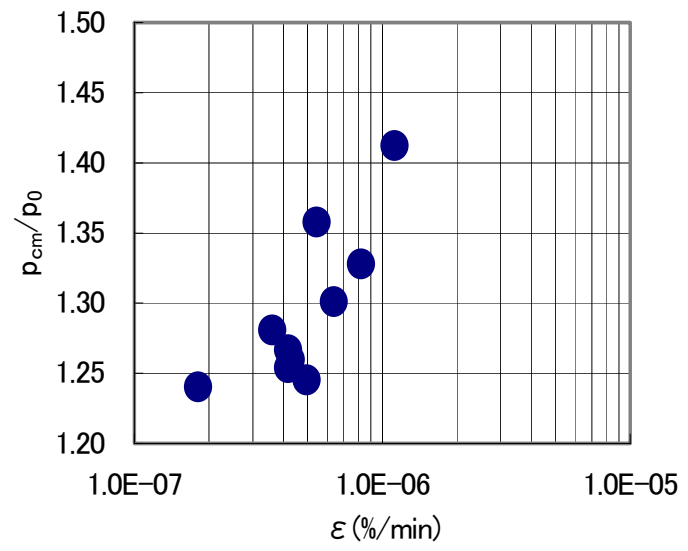

図-22 ひずみ速度 $(\dot{\varepsilon})$ と Pcm $/ P o$ との相関
ずみ速度によって Pcm がどのように変化するかを把握 するために，現地計測により得られた圧密降伏応力 $(P c m)$ を埋立前海底地盤の有効土被り荷重 $(P o)$ て除 した值 $(P \mathrm{~cm} / P o)$ との相関を取ったものが図-22 である. 同図ではひず夕速度と $P \mathrm{~cm} / P o$ （すなわち $O C R ）$ の傾向 が明瞭に表れている. 実測によるひずみ速度は深度が深 くなるにしたがって小さくなっており，OCR も深度とと もに小さくなっている，一方，図-6によると埋立前に実 施した室内試験より得られた OCR は深度とともに大きく なる傾向を示している．これらのことより，当該地の Ma12層上部はひず夕速度の低下とともにOCRが低下寸る 可能性のあることを示唆している.

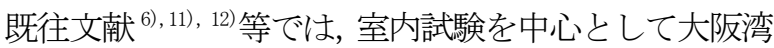
海成粘土のひずみ速度と $P_{C}$ との関係が示されている.今 回の現地計測において埋立荷重は一定ではなく，新たな 盛土による荷重増加や沈下の進行に伴う浮力発生によ る荷重減少などが経時的に発生している，また，ひずみ 速度も複雑な荷重条件のもとで一定期間の平均的な值 で求めている，一方，室内試験においては，ひずみ速度 を一定に保つことが可能であり，そこで示されているひ ずみ速度と今回現地計測で得られたひずみ速度を比較 することができない，今回，現地計測で得られた過圧密 領域のひずみ速度は $1 \times 10^{-6} \sim 10^{-7}(\% / \mathrm{min})$ とかなり小 さいものである. 一方, 表-1によると室内試験での小幅 載荷試験結果によると圧密降伏応力に近いところでの ひずみ速度は $3 \times 10^{-4} \sim 6 \times 10^{-4}(\% / \mathrm{min})$ であり，現地計 測のひずみ速度に比べると 2〜3 オーダー大きい. 既往 文献 ${ }^{11}$ によるとひずみ速度が 2 オーダー小さくなると圧 密降伏応力は, 0.8〜0.9 倍となっており, 今回の室内試 験と現地計測結果から得られた $P_{C}$ の比と一致している. 圧密降伏応力がひずみ速度によって変わることは高位 構造を有寸る擬似過圧密粘土特有の傾向であり ${ }^{6), 99,10)}$, このことが現地の実測データより, 室内試験值と対比す る状態で確認された意義は大きいものと考えられる.

\section{6. まとめ}

前章までの結果をまとめると以下のようになる.

1) 大阪湾海底地盤は擬似過圧密状態であると言われて おり，洪積粘土層の圧密降伏応力 $\left(P_{C}\right)$ など圧密特性 については不明確な部分が多かったが，今回，各種計

表－1 室内試験でのひずみ速度と現地計測によるひずみ速度

\begin{tabular}{|c|c|c|c|c|c|c|}
\hline 海底面からの深度 (m) & 70 & 72 & 77 & 81 & 85 & 90 \\
\hline 現地計測地点での深度 $(\mathrm{m})$ & 91 & 93 & 98 & 102 & 106 & 111 \\
\hline 小幅載荷圧密試験で求められた圧密降伏応力Pc $\left(\mathrm{kN} / \mathrm{m}^{2}\right)$ & 890 & 900 & 900 & 860 & 950 & 1090 \\
\hline 室内試験によるひずみ速度(\%/min) & $4.67 \mathrm{E}-04$ & $3.43 \mathrm{E}-04$ & $3.21 \mathrm{E}-04$ & $4.34 \mathrm{E}-04$ & $4.06 \mathrm{E}-04$ & $6.63 \mathrm{E}-04$ \\
\hline 現地計測によるひずみ速度(\%/min) & $6.38 \mathrm{E}-07$ & $4.18 \mathrm{E}-07$ & $1.59 \mathrm{E}-07$ & $2.86 \mathrm{E}-07$ & $2.01 \mathrm{E}-07$ & $1.67 \mathrm{E}-07$ \\
\hline
\end{tabular}

注）現地計測地点での深度は，埋立層上面からの深度である 
測を行い，その性状がかなり明らかとなった。

2) 圧密降伏応力ついてはひずみ依存性が高いと言われ てきたが，実地盤のひずみ速度が小さい領域で圧密降 伏応力を確認することができた.

3) 室内試験結果と比べると, 現地計測で求められた圧密 降伏応力は小さくなっており，その值は室内試験值の 0.8～1. 0 倍であった. ひずみ速度は 2〜3 オーダー現

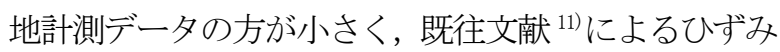
速度による圧密降伏応力低下傾向と一致するもので あった．現地計測で確認できたのは Ma12 層の上部で あるが，下部層においても同様な傾向を示す可能性が 高いものと推察される.

4)Ma12 層の圧縮特性についても上部層では正規圧密領 域に入り，圧縮性が高くなっていたが，下部層におい ては計測段階では過圧密領域であり，大きな圧縮量は 観測されていない.

5)大阪湾洪積粘土の擬似過圧密特性については，これま で主として室内土質試験だけで確認されてきたもの であるが，今回，一部ではあるが現地計測により確認 できた。

6)海成粘土層間の砂礫，砂，粘土の互層部においても， 今回の計測により，相応の排水能力を有することがわ かつた.

これらの結果は，神戸空港を築造するにあたって重要 な情報であり，これらのことを加味して地盤問題解決に 取り組んできた. これらの情報は今後も空港を維持管理 していく上でも貴重な情報になっていくものと思われ る.

謝辞:最後に本計測にあたってお世話になりました関係 各位に厚く感謝申し上げます，あわせて，各種技術課題 を検討する委員会が設けられていましたが，熱心にご審 議していただいた委員各位に深謝いたします.

\section{参考文献}

1) 土質工学会関西支部・大阪湾海底の地盤研究委員会 : 大阪湾海 底地盤, 171p., 1990.

2）土質工学会関西支部・大阪湾地盤情報の活用に関する研究委員 会 : 海底地盤一大阪湾を例として一, 590p., 1995.

3) 大阪湾地盤情報の研究協議会・大阪湾地盤研究委員会 : ベイエ リアの地盤と建設一大阪湾を例として一，505p., 2002.

4) 山本浩司, 田中泰雄, 三村衛, 大島昭彦, 松井保 : 大阪湾海成 粘土層の土質特性と地盤工学的課題, 土と基礎, Vol.53, No.6, pp.10 12, 2005 .

5) Mimura, M. and Jang, W. Y. :Verification of the elasto-viscoplastic approach assessing the long-term deformation of the guasi-overconsolidated Pleistocene clay deposits, 地盤工学会論文報 告集, Vol.45, No.1,pp.37〜49, 2005.

6) Tanaka, H., Udaka, K. and Nosaka, T. : Strain rate dependency of cohesive soils in consolidation settlement, Soils and Foundations, Vol.46, No.3, pp.315 322, 2006.

7) 長谷川憲孝，山本卓生，高橋嘉樹，南部光広，杉浦良行 : 神戸 空港における海底地盤の地盤構成, 第 41 回地盤工学研究発表会,

\section{CD-ROM, 2006.}

8) 長谷川憲孝，山本卓生，高橋嘉樹，南部光広，塚本登士 : 神戸 空港における海底地盤の土質特性, 第41 回地盤工学研究発表会,

\section{CD-ROM, 2006.}

9) 大阪湾海底地盤情報の活用に関する研究委員会 : 海底地盤,

（社）土質工学会関西支部，pp.76 86, 1995.

10) 最上武雄編：土質力学，技報堂, pp.226〜264, 1969.

11) Imai, G, Ohmukai, N. and Tanaka, H.:An isotaches-type compression model for predicting long term consolidation of KIA clays, Proceedings of the Symposium on geotechical Aspects of Kansai International Airport, pp.49 64, 2005.

12) Kobayashi, M., Furudoi, T., Suzuki, S. and Watabe, Y.: Modeling of consolidation characteristics of clays for settlement prediction, Proceedings of the Symposium on geotechnical Aspects of Kansai International Airport, pp.65 76, 2005.

(2006. 5.17 受付) 


\section{IN-SITU CONSOLIDATION BEHAVIOR OF PLEISTOCENE CLAY BELOW SEABED AT KOBE AIRPORT}

\section{Noritaka HASEGAWA, Tamotsu MATSUI, Yasuo TANAKA, Yoshiki TAKAHASHI and Mitsuhiro NAMBU}

Thick deposits of Pleistocene strata are found at deeper depths below the seabed at Kobe Airport which was constructed offshore of Kobe Port. The Pleistocene Clays at the Osaka Bay are quasi-over-consolidated and their consolidation properties have not been well understood. Moreover, the drainage capacity of gravel or sand strata that interlay between the Pleistocene Clays was not clearly understood. In order to examine the settlement behavior of the Clays, a special precise measurement system over a unit depth of 1 or $3 \mathrm{~m}$ intervals was installed to measure both the compressions as well as the excess pore water pressures over the entire depths of the Upper Pleistocene Clays. The measurements covered the compressions of Upper Pleistocene Sand and Gravel layers, and those of Ma12 and uppermost Ma11 Clays that are to be brought into a normally consolidated state due to the airport fill load. Based on the measurements, it was found that the pre-consolidation pressure, $p_{c}$, of Ma12 is function of the strain rate that is highest near the upper drainage boundary and also that the field $p_{c}$ value is smaller than that of the laboratory result because of the low strain rate in the field. The drainage capacity of sand and gravel layers was also found to be good. 